earthquakes, and quantifying how large future earthquakes between the plates might be.

\title{
Tom's Letters: The Private World of Thomas King, Victorian Gentleman.
}

Margot Fry.

Victoria University Press, Wellington, 2001.

Nineteenth-century men in New Zealand have typically been portrayed as dispassionate and detached from their emotional selves, preoccupied as they were with the physical demands of forging a new life. Marriage, too, has been shown in a similar light. As Margot Fry points out in the introductory chapter of Tom's Letters, 'publications about nineteenth-century relationships generally portray marriage as an institution characterised by domination and subjugation' (p. 13). Fry does not intend to tackle this assumption head on-or to turn it on its head-but she argues that this was not always the case. While not contesting the power structures that placed men as head of the household, she proposes that not all men saw marriage in this way. Nineteenth-century marriage was, she maintains, a far more complex institution that the rather rigid stereotype suggests.

Tom's Letters explores this theme by looking closely at the intersection of public and private worlds. Through Thomas King's private letters to his wife, Mary, we catch glimpses of his public life, his role in provincial and national politics. But we also read of his strong emotions towards his wife and children (whom he endearingly refers to as his 'little pledges'). Margot Fry, an independent Wellington historian, began the research for this book while National Library Fellow. Although the book is firmly based on the King family papers, and especially on King's letters to his wife, held by the Alexander Turnbull Library, it is also informed by a wider examination of their historical circumstances and recent scholarship.

The letters cover four quite discrete periods in Tom King's life: firstly a series of letters from his family in England from 1840 to 1848; second, those written in 1846 during his courtship of Mary Chilman, his future wife; thirdly, those from 1854 when Tom attended the General Assembly in Auckland; and lastly, those produced in 1860 when Mary and the children were sent to Nelson. The chapters are organised around these periods and have a fairly regular structure, comprising a historical preface, followed by the lightly edited letters themselves.

Kōtare 4, no. 1 (2001), pp. 73-85. 
The first chapter offers a lively description of the King family in London, including Tom's education, his parents' employment, and his decision to emigrate to New Zealand. The early correspondence concentrates on the distress felt by Tom's mother and sister on his departure in 1840, and the patronage he received from a wealthy relative. The second chapter follows Tom after his arrival in New Zealand and his efforts to 'succeed', first in the settlement at Port Nicholson and then in New Plymouth itself. In chapter three, Fry explores the world of the single male settler and in particular, male friendship and the role of written correspondence in cementing alliances and confirming a path to prosperity. Letters between friends and business acquaintances did not dwell on the personal but addressed the ubiquitous question of how to 'get ahead' and become 'settled', usually in financial rather than domestic terms. Chapter four looks at Tom's courtship of Mary Chilman, as seen through his letters to her. The final chapter considers Tom's relationship with his children, revealing some of his thoughts on family life.

Tom's Letters is, it must be emphasised, much more than a collection of edited letters. Indeed, the contextualising discussions at the beginning of each chapter are of enormous value in their own right. The letters and Fry's careful reading of them allow us to peer into the many worlds of Tom King: father, husband, son, businessman, politician, and settler. Interestingly, there is no real sense from the letters that Tom's worlds collided: he appears to have successfully kept each separate and in its own place. His profound expressions of love for his wife did not spill over into his public life. Tom is happy, for instance, to relate to Mary his experiences attending the General Assembly: but he dwells on the social occasions, his living arrangements, his walks and conversations.

Fry suggests that Tom wrote to Mary about things she might have been interested in-the frequent mention of his spending draws attention to his prudence, a sign that he was being sensible with their money. When Mary and the children are sent to Nelson to escape the war in Taranaki in 1860, Tom writes of the necessity of their remaining there. The letters reveal the practicalities of establishing life in the colony, especially on disputed territory.

But the reader is left with some questions. What about Mary, the recipient of the letters and Tom's chief correspondent? While we get glimpses of her own words in the 1860 series, Mary's voice is otherwise absent. The image we have of her is mediated through Tom's own words. And did Tom write because he had the time to do so-after all, Mary had to attend to the children and undertake all the work in his absence. The fact that there are no extant letters from Mary after 1860 is frustrating. We will never know if the letters provide a 'typical' snapshot

Kōtare 4, no. 1 (2001), pp. 73-85. 
into nineteenth-century life and love or whether it was an extreme case forced by separation. But these questions relate more to the nature of the material than Fry's interpretation of it. To some extent these questions simply reflect the fragmentary and partial nature of this kind of historical evidence.

Tom's Letters is a book of many strengths. It succeeds in supporting two main analytical threads: the analysis of the King material and the integration of current historiographical debate. Fry relates her close readings of the letters to recent scholarly observations about family, the private lives of nineteenthcentury men, love and courtship. These discussions do not distract from the narrative but enhance and 'flesh out' the personality of Tom King. Toms' Letters is therefore an important contribution to our understanding of nineteenth-century social relationships. It complements other works that have illuminated the lives of women in the nineteenth-century, both in New Zealand and further afield. And in exploring the life of early settler New Plymouth, the book sits alongside Frances Porter's biography of Jane Maria Atkinson, Born to New Zealand (1989). Like Miles Fairburn's Nearly Out of Heart and Hope (1995), it shows just how rewarding a close reading of one person's life can be.

An immensely enjoyable and satisfying book, Tom's Letters is carefully considered, well written, lively and engaging. It does not attempt any grand generalisations but aims instead to unsettle our notions and assumptions of marriage, love and intimacy in the nineteenth century. I finished the book wanting to know more about Tom and his family's life after 1860 when the letters end: but the book focuses on the journey itself, rather than the destination. In the end, Fry succeeds in bringing Tom King, in all his facets, to life. Tom's Letters is a timely reminder that nineteenth-century men, like nineteenth-century women, were no less complex, difficult or contradictory than ourselves.

Dr. Giselle Byrnes lectures in History at the Victoria University of Wellington.

\section{Notice}

"as fair as New Zealand to me"

Victoria University Press, Wellington, 2000.

The full title of this book indicates something of its context and purpose: "as fair as New Zealand to me" New Zealand Writers in Katherine Mansfield's Menton

Kōtare 4, no. 1 (2001), pp. 73-85. 